The sensitivity of the method is about $0 \cdot 3 \gamma$ of base. This high sensitivity makes it worth while to attempt the resolution of racernic mixtures into their optical antipodes by these means. Experiments on such applications are in progress.

G. B. BonIno

V. Carassiti

Centro Studi di Chimica Fisica del C.N.R.,

Istituto Chimico "Giacomo Ciamician", Università di Bologna. Nov. 22.

' Dent, C. E., Biochem. J., 43, 169 (1949). Zechmeister, L., "Stereochemistry and Chromatography", Ann. New York Acad. Sci., 49 graphie", 37 (Paris : Herman, 1949). Flood, A. E., Hirst, E. L. and Jones, J. K. N., J. Chem. Soc., 1679 (1948).

- Betti, M., Gazz. Chim. Ytal., 31, I, 386 (1901); 36, II, 392 (1906).

${ }^{a}$ Consden, R., Gordon, A. H., and Martin, A. J. P., Biochem. J., 38 224 (1944).

\section{Abnormal Colour of Chelate Compounds}

A LARGE number of deeply coloured chelate compounds is known, the components of which show no, or only weak, absorption in the visible region. Typical examples are the nickel complex of diacetyl dioxime and the ferrous tri- $\alpha-\alpha^{\prime}$-dipyridyl and tri-ophenanthroline ions. As such complexes have been shown to be diamagnetic ${ }^{1}$, containing thus closed electronic shells on the metal atom, it is highly improbable that the colour of such compounds is due to electronic transitions within the metal atoms. The abnormal colour can thus be only attributed to the co-ordinated molecules ${ }^{2}$.

Comparing the visible and ultra-violet absorption spectra of the ferrous tri- $\alpha$ - $\alpha^{\prime}$-dipyridyl ion ${ }^{3}$, we found, as shown in the accompanying diagram, a striking similarity. Both the visible and ultra-violet spectra show not only the same two-band system, but also the same qualitative structure of the absorption bands. This finding makes it highly probable that

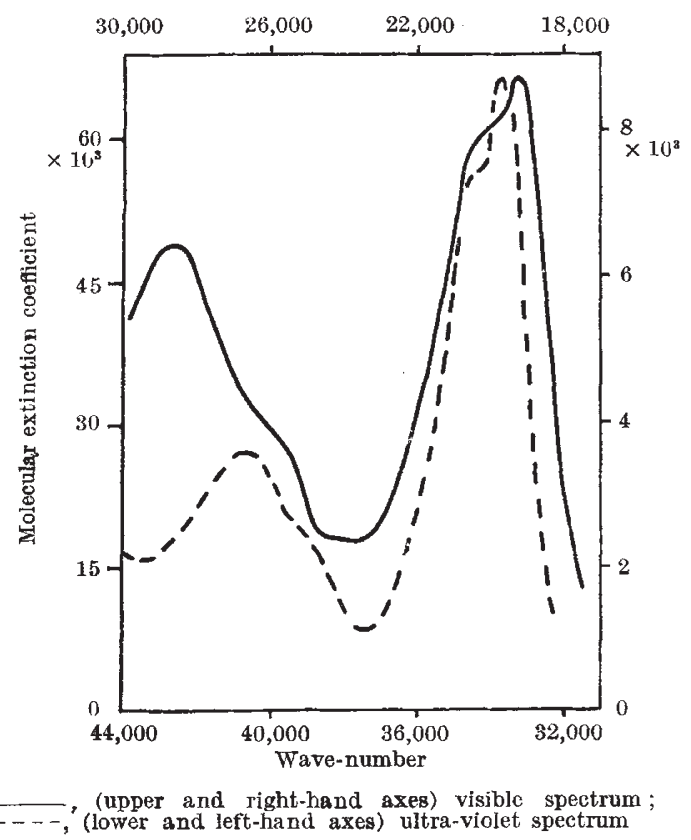

the absorption in the visible region is really due to the co-ordinated molecules and, furthermore, that the corresponding electronic transitions are of essentially the same kind as the transitions in the ultra-violet region. The ultra-violet spectrum of the ferrous tri- $\alpha-\alpha^{\prime}$-dipyridyl ion is similar to the spectrum of $\alpha-\alpha^{\prime}$-dipyridyl and its salts ${ }^{4}$. It is thus probably due to slightly modified transitions within the individual co-ordinated molecules. We believe that the visible spectrum is due to transitions of a similar kind involving the entire polynuclear chelate system.

The example discussed seems to be exceptional. The very similar ferrous tri-o-phenanthroline ion shows no such similarity between its visible and ultra-violet absorption.

The structural questions involved will be discussed in detail elsewhere.

\section{P. Krumholz}

Research Laboratory of Orquima S.A., São Paulo, Brazil.

Nov. 11.

${ }^{1}$ See literature references in P. W. Selwood, "Magnetochemistry" (Interscience Pub., New York, 1943).

2 Recently, Roberts, G. L., and Field, F. M., J. Amer, Chem. Soc., 72, $4222(1950)$, interpreted in this way the absorption of the nickel tri-o-phenanthroline ion between 300 and $350 \mathrm{~m} \mu$.

The absorption spectra of this compound have already been reported ; see, for example, Yamasaki, R., Chem. Abstr., 35, 1700 (1941); Baxendale, J. H., and George, Philip, Trans. Farad. Soc., 46, $55(1950)$.

Baxendale, J. H. (ref. 3).

\section{Revised Empirical Formula for Eburicoic Acid}

IN our recent communication ${ }^{1}$ on this acid, melting point $293^{\circ}$, the empirical formula $\mathrm{C}_{27} \mathrm{H}_{44} \mathrm{O}_{3}$ was adopted in preference to $\mathrm{C}_{30} \mathrm{H}_{48} \mathrm{O}_{3}$ originally proposed by Kariyone and Kurono ${ }^{2}$. Following upon a more detailed examination of this compound and its degradation products, in conjunction with the results of molecular-weight determinations according to the method of Ruzicka and Furter ${ }^{3}$ with oleanolic and betulic acids as the standard, we have now established that eburicoic acid has the formula $\mathrm{C}_{30} \mathrm{H}_{48} \mathrm{O}_{3}$ (found: $\mathrm{C}, 78.9 ; \mathrm{H}, 10.5$; mol. wt. (by titration), $459-462 ; \mathrm{C}_{30} \mathrm{H}_{48} \mathrm{O}_{3}$ requires $\mathrm{C}, 78.9 ; \mathrm{H}, 10.5$ per cent; mol. wt., 457). A re-investigation of the following derivatives described in the earlier note ${ }^{1}$ affords results in complete agreement with the $\mathrm{C}_{30}$-formula : $\mathrm{O}$-acetyl eburicoic acid (m.p. 256-257 ; found: $\mathrm{C}, 77.0 ; \mathrm{H}, 10 \cdot 0 . \mathrm{C}_{32} \mathrm{H}_{50} \mathrm{O}_{4}$ requires $\mathrm{C}$, 77.0 ; H, 10.1 per cent), methyl eburicoate (m.p. 140-141 ; found: $\mathrm{C}, 79 \cdot 1$; $\mathrm{H}, 10 \cdot 5 . \mathrm{C}_{31} \mathrm{H}_{50} \mathrm{O}_{3}$ requires $C, 79 \cdot 1 ; H, 10 \cdot 7$ per cent), methyl $O$-acetyleburicoate (m.p. 153-154 ; found : C, 77.5; H, 10.3. $\mathrm{C}_{33} \mathrm{H}_{52} \mathrm{O}_{4}$ requires $\mathrm{C}, 77 \cdot 3 ; \mathrm{H}, 10 \cdot 2$ per cent), and $p$-nitrobenzyl eburicoate (m.p. 150-5 ; found : $\mathrm{C}, 74 \cdot 8 ; \mathrm{H}, 9 \cdot 2 ; \mathrm{N}, 2 \cdot 5 . \quad \mathrm{C}_{37} \mathrm{H}_{53} \mathrm{O}_{5} \mathrm{~N}$ requires $\mathrm{C}$, $75 \cdot 0 ; \mathrm{H}, 9 \cdot 0 ; \mathrm{N}, 2 \cdot 4$ per cent).

\section{R. M. GascoIGNE \\ J. S. E. HOLKER \\ B. J. RALPH \\ ALEXANDER ROBERTSON}

Department of Organic Chemistry,

University of Liverpool. Jan. 17.

${ }^{1}$ Gascoigne, Holker, Ralph and Robertson, Nature, 166, 652 (1950). 2 Kariyone and Kurono, J. Pharm. Soc., Japan, 60, 110, 318 (1940).

${ }^{3}$ Ruzicka and Furter, Heiv. Chim. Acta, 15, 472 (1932), 